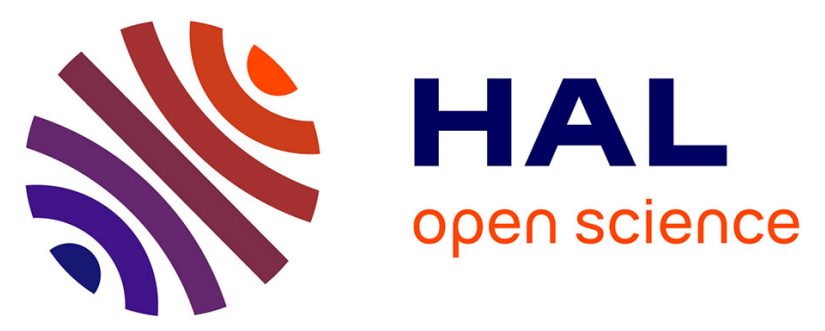

\title{
Effect of electrodeposition duration on the morphological and structural modification of the flower-like nanostructured $\mathrm{ZnO}$
}

N. Ait Ahmed, H. Hammache, L. Makhloufi, Marielle Eyraud, S. Sam, A. Keffous, N. Gabouze

\section{To cite this version:}

N. Ait Ahmed, H. Hammache, L. Makhloufi, Marielle Eyraud, S. Sam, et al.. Effect of electrodeposition duration on the morphological and structural modification of the flower-like nanostructured $\mathrm{ZnO}$. Vacuum, 2015, 120, pp.100-106. 10.1016/j.vacuum.2015.04.009 . hal-02499503

\section{HAL Id: hal-02499503 \\ https://hal-amu.archives-ouvertes.fr/hal-02499503}

Submitted on 6 Mar 2020

HAL is a multi-disciplinary open access archive for the deposit and dissemination of scientific research documents, whether they are published or not. The documents may come from teaching and research institutions in France or abroad, or from public or private research centers.
L'archive ouverte pluridisciplinaire HAL, est destinée au dépôt et à la diffusion de documents scientifiques de niveau recherche, publiés ou non, émanant des établissements d'enseignement et de recherche français ou étrangers, des laboratoires publics ou privés. 


\title{
Effect of electrodeposition duration on the morphological and structural modification of the flower-like nanostructured $\mathrm{ZnO}$
}

\author{
N. Ait Ahmed ${ }^{1,2}$, H. Hammache ${ }^{1}$, L. Makhloufi ${ }^{1}$, M. Eyraud ${ }^{3}$, S. Sam ${ }^{2}$, A. Keffous ${ }^{2}$, \\ N.Gabouze ${ }^{2}$ \\ ${ }^{1}$ Laboratoire d'Electrochimie, Corrosion et de Valorisation Energétique (LECVE), Université \\ de Bejaia, 06000 Bejaia, Algérie. \\ ${ }^{2}$ Centre de Recherche en Technologie des Semiconducteurs pour l'Energétique (CRTSE), 2, \\ bvd. Frantz Fanon, B.P. 140 Alger 7 Merveilles, Alger, Algérie. \\ ${ }^{3}$ Aix-Marseille University, CNRS, MADIREL, UMR 7246, Equipe Electrochimie des \\ Matériaux, 13397 Marseille Cedex 20, France
}

\begin{abstract}
Flower-like morphology of $\mathrm{ZnO}$ thin films were successfully electrodeposited via a one-step route only by changing electrodeposition duration and potential at a fixed concentration on nSi (100) in78.10-4 $\mathrm{M} \mathrm{Zn}\left(\mathrm{NO}_{3}\right)_{2}, 6 \mathrm{H}_{2} \mathrm{O}$ and $0.1 \mathrm{M} \mathrm{KNO}_{3}$ solution at $70{ }^{\circ} \mathrm{C}$ without using any catalyst, additives or seed layer. The as electrodeposited products were characterized by X-ray diffraction, scanning electronic microscopy and photoluminescence. The effects of the electrodeposition potential and duration on the morphology, structure and photoluminescence properties were studied. The results show that the product morphology changes with a change in the applied voltage and electrodeposition duration. Well defined shape of flower like $\mathrm{ZnO}$ morphology was generated under the limited conditions of $-1.2 \mathrm{~V}$ for $60 \mathrm{~min}$, with (002) preferred orientation Strong UV emission is obtained in the case of $\mathrm{ZnO}$ flower like morphology electrodeposited at $-1.2 \mathrm{~V}$ for $60 \mathrm{~min}$. The band gap energy value of $\mathrm{ZnO}$ flower-like, determinate from optical reflectance spectra, is $3.37 \mathrm{eV}$.
\end{abstract}

Keywords: $\mathrm{ZnO}$, Electrodeposition, thin films, zinc nitrate, band gap. 


\section{Introduction}

Zinc oxide is a very important semiconductor with a wide direct band gap of $3.37 \mathrm{eV}$ and a large exciton binding energy of $60 \mathrm{meV}$ [1], which have been widely applied in UV luminescence [2], photovoltaic cells [3], light-emitting diodes [4], nanogenerators [5], dyesensitized solar cells (DSSCs) [6-8] and quantum dots-sensitized solar cells (QDSCs) [9]. Because the properties of determining the performance of $\mathrm{ZnO}$-derived devices strongly depend on the size and the shape, precision control of the morphology of $\mathrm{ZnO}$ crystals is a matter of considerable importance for exploring the potential oxide material. Specially, hierarchical nanostructures using lower dimension nanocrystals as the building blocks attract more interest due to their less gas diffusion length, higher mobility, and relatively larger specific surface area than the agglomerated nanoparticles [10]. $\mathrm{ZnO}$ with different dimensional nanostructures have been synthesized such as nanocombs, nanopropellers, nanobridges, nanoflowers [11-15] and many other hierarchically complex micro/nanostructures [16-18].

Up to now, a variety of routes have been employed to obtain $\mathrm{ZnO}$ nanostructures with various morphologies such as chemical vapor deposition [19, 20], sol-gel [21-23], radio frequency sputtering [24], pulsed laser deposition [25], spray-pyrolysis [26], chemical oxidation of $\mathrm{Zn}$ [27] and so on.

Recently, electrodeposition emerged as a competitive technique for the fabrication of semiconducting thin films [28-30]. Very thin layers with specific composition, morphology and good adhesion between the deposited films and the substrates can be easily prepared by electrochemical techniques. This technique presents a rapid and cost-effective method for preparation of large-area $\mathrm{ZnO}$ thin films with high orientation degree [31-32]. In the past decade, a wide variety of $\mathrm{ZnO}$ crystals were prepared by electrodeposition [28-33] 
Number of papers are focused on the various morphologies of $\mathrm{ZnO}$ crystals in relation to the preparation conditions, including the role of seeds or templates, and the presence of organic molecules as a shape modifier [29-39]. ZnO nanorods, nanowires or nanofils can be usually grown on templates such as titanium nanotubes [29], anodic alumina membrane [34, 35], nanoporous polycarbonate membrane [36, 37], or polymer membrane [38, 39].

Despite the different methods discussed, it still remains a challenge for researchers to develop a facile route to synthesize shape-selective $\mathrm{ZnO}$ hierarchical nanostructures that does not use any toxic reagents or any organic additives. The three-dimensional, complex structures of $\mathrm{ZnO}$, such as stars, dendrites, and flowers, have recently drawn increased attention because of their unique properties. In particular, $\mathrm{ZnO}$ nanoflowers offer large surface area and enhance light scattering capacity $[40,41]$ and thus expected to be applied in sensors, photocatalysis and photoelectrochemical cells (DSSCs or QDSCs). At present, many different ZnO nanoflowers including self-assembled nanorods [42], self-assembled nanosheets [43], and other shaped nanoflowers [44] have been successfully synthesized by various physical and chemical methods. Most $\mathrm{ZnO}$ flower-like structures are synthesized using the hydrothermal method [45, 46] and research into the synthesis of $\mathrm{ZnO}$ flower-like structures by electrodeposition is limited and needs the use of seeds, precursor and also post-heat treatment [31, 41, 47-51].

For example, Y.C. Liang [47] synthesized $\mathrm{ZnO}$ flower-like structures of different sizes on polycrystalline zinc foils by cathodic electrodeposition at $90^{\circ} \mathrm{C}$, using hexamethylenetetramine (HTM). Also, F. Xu et al [48] reported the electrodeposition of hexagonal flower-like ZnO bundles on indium tin oxide (ITO) glass from an equimolar $(0.005 \mathrm{M})$ aqueous solution of $\mathrm{Zn}\left(\mathrm{NO}_{3}\right)_{2}$ using hexamethylenetetramine $(\mathrm{HTM})$ as directing agent. In the same conditions, they reported [49] the preparation of complex 3D flower-like structures composed of dozens of individual petals on Au/ITO glass, pointing out the crucial roles of Au seed layer in determining final surface microstructures of the products. 
In 2012, the electrodeposition and subsequent heat treatment process to synthesize the $\mathrm{ZnO}$ micro/nanostructure are investigated by Q. Hou et al. [41] and J-li. Yang et al [50]. Flower-like $\mathrm{Zn}_{5}(\mathrm{OH})_{8}\left(\mathrm{NO}_{3}\right)_{2}\left(\mathrm{H}_{2} \mathrm{O}\right)_{2}$ precursor assembled by ultra thin sheets are prepared by. electrodeposition method and were converted to flower-like $\mathrm{ZnO}$ nanosheets after a heat treatment process

In this work, $\mathrm{ZnO}$ flower-like morphology was prepared by electrochemical deposition (ECD) method from aqueous zinc nitrate solution at $70^{\circ} \mathrm{C}$ onto silicon n-type Si (100) substrates via a one-step electrodeposition rout only by changing electrodeposition duration and potential at a fixed concentration. To our best knowledge this morphology is not reported elsewhere without using reactive catalyst, additives directing agent, seed layer or post-heat treatment. The effect of synthesis duration and potential on the morphology, structure and crystallographic form of $\mathrm{ZnO}$ thin films is investigated by the techniques of SEM and XRD. Moreover PL and UV measurements were performed to study the optical proprieties of the obtained $\mathrm{ZnO}$ thin films.

\section{Experimental details}

The $\mathrm{ZnO}$ nanostructures were prepared by cathodic potentiostatic electrochemical deposition. Cyclic voltammetry $(\mathrm{CV})$ and potentiostatic electrodeposition were performed using a potentiostat/galvanostat (Autolab PGSTAT30) coupled with HP computer under "Voltamaster logitiel". The electrodeposition was carried out in a classical three electrodes system, where Pt served as the counter electrode, a saturated calomel electrode (SCE) as reference, and n-type Si (100) electrode of $7 \Omega \mathrm{cm}$ resistivity as working electrode. The aqueous electrolyte used here was zinc nitrate, $78.10^{-4} \mathrm{M} \mathrm{Zn}\left(\mathrm{NO}_{3}\right)_{2}, 6 \mathrm{H}_{2} \mathrm{O}$ with $0.1 \mathrm{M} \mathrm{KNO}_{3}$ with an initial $\mathrm{pH}$ of 6.5 and the growth temperature was set at $70^{\circ} \mathrm{C}$. Zinc nitrate $\left(\mathrm{Zn}\left(\mathrm{NO}_{3}\right)_{2}, 6 \mathrm{H}_{2} \mathrm{O}\right)$ and potassium nitrate $\left(\mathrm{KNO}_{3}\right)$ were purchased from Sigma-Aldrich (98\%) and Fluka (98\%) products respectively and were used as received. All solutions were prepared with deionized water purified with a 
Millipore Milli-Q purification system $(18 \Omega \mathrm{cm})$. Before electrochemical measurements, the silicon wafers was cleaned sequentially with acetone (5 min), ethanol ( $5 \mathrm{~min})$, deionized water (2-3 min), and $\mathrm{H}_{2} \mathrm{SO}_{4} / \mathrm{H}_{2} \mathrm{O}_{2}\left(1 / 3 \mathrm{H}_{2} \mathrm{SO}_{4}(97 \%) / \mathrm{H}_{2} \mathrm{O}_{2}(30 \%), 10 \mathrm{~min}\right)$, then the wafers were thoroughly rinsed with deionized water (10 min) and dipped into a solution of HF (1 $\mathrm{min})$ [41]. To study the effect of applied voltage, the electrochemical growth of $\mathrm{ZnO}$ onto the Si (100) electrode was carried out at $-1.2 \mathrm{~V}$ and $-1.4 \mathrm{~V}$ versus SCE reference electrode. The influence of electrodeposition duration (i.e., 10, 20, 40 and $60 \mathrm{~min}$ ) of $\mathrm{ZnO}$ was also investigated.

The surface morphology of the $\mathrm{ZnO}$ nanostructures was examined by scanning electron microscopy (SEM) by using a Philips XL 30 ESEM. The Si-Li electrode was used for light elements with a $133 \mathrm{eV}$ resolution at low rate counting with beam parameters of $20 \mathrm{keV}$ and 160 pA. X-ray diffraction (XRD) analyses were performed on a Siemens D5000 diffractometer using filtered $\mathrm{CuK} \alpha(\lambda=0.15406 \mathrm{~nm})$ as a radiation source. The diffractometer was operated at $40 \mathrm{kV}$, room temperature, with a scanning rate of $10^{\circ} \mathrm{min}^{-1}$. The XRD analyses were carried out for the scattering angle ranging between $25^{\circ}$ and $65^{\circ}$.

The photoluminescence measurements were carried out at room temperature, to investigate the optical properties of the samples using a Perkin-Elmer LS-50B luminescence spectrometer under an excitation wavelength of $325 \mathrm{~nm}$ Xe lamp with a scan rate of $300 \mathrm{~nm} \mathrm{~min}{ }^{-1}$. UV-vis diffuse reflectance spectra of the samples were performed at room temperature in the range of 300-800 nm using a Varian 300 spectrophotometer equipped with an integrating sphere DRACA-30I recorded on a Hitachi U-3310.

\section{Results and discussion}

Cyclic voltammetry study was performed in a potential range of -0.5 to $-1.5 \mathrm{~V} / \mathrm{ECS}$ onto a silicon substrate from an aqueous solution containing $78.10^{-4} \mathrm{M} \mathrm{Zn}\left(\mathrm{NO}_{3}\right)_{2}, 6 \mathrm{H}_{2} \mathrm{O}$ and $0.1 \mathrm{M}$ $\mathrm{KNO}_{3}$ at $\mathrm{pH}=6.5$. The potential scan was initiated in the negative direction from the open 
circuit potential (OCP) at a scan rate of $5 \mathrm{mVs}^{-1}$ (Figure 1(a)). For comparison, a cyclic voltammogram obtained in $\mathrm{KNO}_{3} 0.1 \mathrm{M}$ solution free zinc ions is presented in Figure 1(b). Figure 1(a) shows that there is no current flows until the potential becomes more negative than about $-1.1 \mathrm{~V}$. Below that value, the cathode current increases gradually with the potential, indicating the formation of $\mathrm{ZnO}$. $\mathrm{In}_{\mathrm{KNO}_{3}}$ solution, the nitrate into nitrite reduction is involved with equilibrium potential evaluated neglecting the $\mathrm{NO}_{2}{ }^{-}$concentration to be close to 170 $\mathrm{mV} / \mathrm{SCE}$. The current performed on curve $\mathrm{b}$ reveals that the reduction of nitrate into nitrite ions on Si (100) substrate occurs before $\mathrm{ZnO}$ formation. Accordingly, nitrate reduction results in formation of hydroxide ions and hence causes the precipitation of zinc hydroxide onto the cathodic electrode, which is finally dehydrated into $\mathrm{ZnO}$. This mechanism of electrodeposition is simply described as follows [31].

$$
\begin{aligned}
& \mathrm{NO}_{3}^{-}+\mathrm{H}_{2} \mathrm{O}+2 e^{-} \rightarrow \mathrm{NO}_{2}^{-}+2 \mathrm{OH} \\
& \mathrm{Zn}^{2+}+2 \mathrm{OH}^{-} \rightarrow \mathrm{Zn}(\mathrm{OH})_{2} \rightarrow \mathrm{ZnO}+\mathrm{H}_{2} \mathrm{O}
\end{aligned}
$$

No anodic peak is observed in the reverse scan (Figure 1(a)), indicating that no zinc metal is obtained in the cathodic scan [32]. This behavior indicates that the electrochemical deposition of $\mathrm{ZnO}$ is an irreversible reaction. Accordingly no $\mathrm{ZnO}$ deposit is obtained for potential more anodic than $-1.1 \mathrm{~V}$ and high deposition rate is obtained for a potential more cathodic than -1.1 $\mathrm{V}$; thus a cathodic potentials of $-1.2 \mathrm{~V}$ and $-1.4 \mathrm{~V}$ were selected to deposit $\mathrm{ZnO}$ thin films. The growth rate can successfully tuned by varying the cathodic potential.

In order to investigate the effect of the electrodeposition potential and duration on the crystalline structure of $\mathrm{ZnO}$ thin films, XRD analysis were performed on $\mathrm{Si}(100)$ substrate at $-1.2 \mathrm{~V}$ and -1.4 V versus SCE for different electrodeposition duration (Figure 2(A and B) respectively. It can be seen that all patterns have similar peaks at $2 \theta=31.98^{\circ}, 34.54^{\circ}, 36.46^{\circ}$ and $54.2^{\circ}$ corresponding to the (100), (002), (101) and (102) planes of $\mathrm{ZnO}$, respectively, which 
correspond to the typical diffraction peaks of hexagonal wurtzite $\mathrm{ZnO}$ (with reference to JCPDS No. 36-1451). The presence of several peaks in the XRD reveals that the films are polycrystalline. No peaks from other compounds are detected besides those from $\mathrm{ZnO}$. It can be noted from Figure 2 that the increase of electrodeposition duration leads to the increase of (002) peaks intensities, indicating a preferential orientation along the (002) plane perpendicular to the substrate. Previous researches show similar results in $\mathrm{ZnO}$ films prepared by electrodeposition from aqueous solutions [52,53], but C. Gu et al found that, the (002) preferred orientation of $\mathrm{ZnO}$ films was weakening with the increase of deposition times [54].

It can also be noted from Figure 2(A) that the (002) preferential orientation is more pronounced at $-1.2 \mathrm{~V}$ potential, in accordance with the results in our previous work [32] and those of $\mathrm{M}$. Izaki et al [55]. However, our results are in contrast to those from other references [47, 56, 57], where the authors claimed that the preferential orientation of the electrodeposited $\mathrm{ZnO}$ films changed from (002) to (100) plane with increasing cathodic potential. Nevertheless, in these papers, the substrates are different (zinc, copper or ITO) and the influence of the substrate on the mechanism of electrodeposition has already been clearly established in our previous work $[32]$.

The preferential growth orientation was determined using a texture coefficient TC (hkl). This factor is calculated using the following relation $[58,59]$ :

$\mathrm{TC}_{(002)}=\frac{I_{(002)} / I_{(002)}^{\circ}}{1 / N \sum_{n}{ }^{{ }^{(h k l)}} / I_{(h k l)}^{\circ}}$

where TC $\left(\begin{array}{lll}0 & 0\end{array}\right)$ is the texture coefficient of the $\left(\begin{array}{lll}0 & 0 & 2\end{array}\right)$ plane, $\left.I_{(} k_{k}\right), I_{(}\left(\begin{array}{lll}0 & 2\end{array}\right)$ are the measured intensities, $\mathrm{I}^{0}{ }_{(\mathrm{hkl})}, \mathrm{I}^{0}{ }_{(002)}$ are the recorded intensities according to the JCPDS 036-1451 card [60, 61], $\mathrm{N}$ is the reflection number and $\mathrm{n}$ is the number of diffraction peaks. 
A sample with randomly oriented crystallite yields $\mathrm{TC}_{\left(\mathrm{h} \mathrm{k}_{\mathrm{l}}\right)}=1$, while the larger this value, the larger abundance of crystallites oriented at the ( $\mathrm{h} \mathrm{k}$ l) direction. The calculated texture coefficients TC are presented in Table 1. It can be seen that the highest TC is obtained for the ( $\left.\begin{array}{lll}0 & 0 & 2\end{array}\right)$ plane of the $\mathrm{ZnO}$ thin film at $-1.2 \mathrm{~V}$ for $60 \mathrm{~min}$. The higher values of texture coefficient indicate good crystallinity of the films. As the electrodeposition time increases the lateral growth is constrained due to the compactness of the flower-like and thus improves the alignment of flower-like and the texture becomes more perfect with growth time as revealed by the XRD. It can also be seen from table. 1 that increasing the cathode potential from $-1.2 \mathrm{~V}$ to $1.4 \mathrm{~V}$ decreases the texturing of the films.

The effects of the electrodeposition potential and duration on the morphology of $\mathrm{ZnO}$ were studied using scanning electron microscopy (SEM). Figure 3 shows SEM images for the thin films obtained at $-1.2 \mathrm{~V}$ and $-1.4 \mathrm{~V}$ for 20,40 and $60 \mathrm{~min}$. It illustrates a $\mathrm{ZnO}$ morphology evolution from flower-like to nanorod by varying electrodeposition potential and duration. At potential of $-1.2 \mathrm{~V}$ (Figure 3 (a-c)), a few $\mathrm{ZnO}$ nucleus were generated on the Si (100) substrate and grew to $\mathrm{ZnO}$ nanorods. With electrodeposition time prolonging, nanorods fused together to form bunch of flower-like structure composed of closely packed nanorods which appear to extend radially from the center and grown in very high density and fully cover the Si substrate. As the electrodeposition time increases the lateral growth is constrained due to the compactness of the nanorods and thus improves the alignment of nanorods and the texture becomes more perfect with growth time as revealed by the XRD analysis. The as-fabricated flower-like structures are made up of several hexagonal-shaped petals and possess sharp tips and wider bases. These wider bases are connected with each other in such a special fashion that they make flower-like morphologies. The typical diameters at the tips and bases of petals are $\sim 100 \mathrm{~nm}$. The lengths of petals are in the range of 300-500 $\mathrm{nm}$. The high-magnification SEM image of the deposited shown in Figure $3 \mathrm{c}$, illustrates the flower-like $\mathrm{ZnO}$ morphology growing along 
c-axis direction. Branched structures were observed and each individual branch consists of stacking hexagonal grown perpendicularly on the substrate layer by layer.

The morphology of the thin films obtained at $-1.4 \mathrm{~V}$ for 20,40 and $60 \mathrm{~min}$ is presented as nanorods of different sizes (Figure 3 (d-f)). It can be observed that few nanorods are present on the Si substrate for 20 min (Figure 3 (d)) and that the number and the cristallinity of nanorods increase with the increase of electrodeposition duration. When the applied potential increased from -1.2 to $-1.4 \mathrm{~V}$ (Figure 3 ) the density of nanorods increased and their average diameters decreased. Apparently, the smaller diameter and random growth of nanorods might be caused by the nanorods higher density. From above, it is evident that the cathodic polarization controls the rate of formation of new nuclei during the deposition process and the nucleation density of electrodeposits increases with the increase in overpotential. Therefore, applying a relatively low potential $(-1.2 \mathrm{~V})$, the reduction of nitrate reacted slowly and no enough $\mathrm{OH}^{-}$was formed. A few $\mathrm{ZnO}$ nucleus were generated on the $\mathrm{Si}(100)$ substrate and grew to $\mathrm{ZnO}$ nanorods with a bigger size and taller height. As a higher potential applied, not only reduction of nitrate increased, the formation of $\mathrm{ZnO}$ nucleation also increased. High nucleation density led to smaller diameter and larger density as shown in (Figure $3(\mathrm{~d}-\mathrm{f})$ ). This is presumably because under more negative potential, the growth of $\mathrm{ZnO}$ would rapidly take place on some specific sites with a lower energy barrier, thus leading to a higher rate of $\mathrm{ZnO}$ deposition. Moreover, it should to be noted that the smaller diameter and random growth of nanorods might be caused by the hydrogen evolution that occurred at the cathode surface.

The photoluminescence (PL) properties of $\mathrm{ZnO}$ flower-like and nanorods morphology prepared at $-1.2 \mathrm{~V}$ and $-1.4 \mathrm{~V}$ for $60 \mathrm{~min}$ are shown in Figures 4(a and b), respectively. As shown in (Figure 4(a)), three emission regions are observed for the film deposited at $-1.2 \mathrm{~V}$ for $60 \mathrm{~min}$ with a maximum emission in the UV region at $383 \mathrm{~nm}$. The other two bands are located in the blue, $434 \mathrm{~nm}$ and $521 \mathrm{~nm}$ to about lower intensity. The strong and sharp ultraviolet emission 
centered at $383 \mathrm{~nm}$ called as the near band edge emission may originate from the recombination of the free excitons through an exciton-exciton collision process $[62,63]$ as $\mathrm{ZnO}$ has a high exciton-binding energy of $60 \mathrm{meV}$ at room temperature [1]. The appearance of blue emission bands is related to the variation of the intrinsic defects in $\mathrm{ZnO}$ films, such as zinc vacancy ( $\mathrm{Vzn})$, oxygen vacancy $(\mathrm{Vo})$, interstitial zinc $\left(\mathrm{Z}_{\mathrm{ni}}\right)$, interstitial oxygen $\left(\mathrm{O}_{\mathrm{i}}\right)$, and antisite oxygen $\left(\mathrm{O}_{\mathrm{Zn}}\right)$ [64]. As the electrodeposition potential increases from $-1.2 \mathrm{~V}$ to $-1.4 \mathrm{~V}$ the $\mathrm{UV}$ emission became weaker and the blue and green ones at $433 \mathrm{~nm}$ and $522 \mathrm{~nm}$ increases (Figure 4(b)). The green band emission can be attributed to the singly ionized oxygen vacancy and resulted from the recombination of photogenerated hole with the single ionized charge state of this defect [65]. Godlewski et al. indicated that poor morphology and granular features are the key reasons why the UV photoluminescent peak intensity may become weak [66]. The concentration of oxygen vacancy defects was possibly decreased when $\mathrm{ZnO}$ flower-like were prepared at $-1.2 \mathrm{~V}$, which resulted in the decrease of the PL intensity in the green luminescence region as shown in (Figure 4(a)). Therefore, it was reasonably believed that the as-prepared flower-like $\mathrm{ZnO}$ nanostructures possessed a low concentration of oxygen vacancies and high optical quality of single-crystal.

UV-vis spectroscopy was also performed to examine the optical property of as-electrodeposited ZnO flower-like at $-1.2 \mathrm{~V}$ for 60 min onto Si (100) substrate. The most convenient method for determining the bandgap energy is from transmittance spectroscopy; but it is not possible to measure the transmitted spectra for thin films grown onto opaque substrates and the thin films can be separated onto a new transparent one [67]. Nevertheless, for studying the band gap energy in the as-grown conditions, optical reflectance may also be used [68]. Figure 5 (a), shows $\mathrm{UV}-\mathrm{Vis}$ diffuse reflectance spectra represented in the UV-blue optical region.

The reflectance spectra of the $\mathrm{ZnO}$ flower-like was obtained by the diffuse reflectance spectroscopy (DRS) signal [69]; i.e. 


$$
\mathrm{R}_{\mathrm{ZnO} / \mathrm{Si}}(\lambda)=\frac{\mathrm{Rzno}_{\mathrm{Zn}}(\lambda)}{\mathrm{Rsi}_{\mathrm{si}}(\lambda)}
$$

Eq.4

where $\mathrm{RZnO}_{\mathrm{ZnO}}(\lambda)$ is the reflectance of the whole sample ( $\mathrm{ZnO}$ deposited onto silicon), $\mathrm{R}_{\mathrm{Si}}(\lambda)$ is the silicon substrate reflectance and $\mathrm{RznO} / \mathrm{Si}(\lambda)$ is the DRS signal which is entirely due to the film optical properties.

This bandgap energy determination method is based on the fact that for direct semiconductors, as $\mathrm{ZnO}$, Reflectance $(\mathrm{R})$ was converted into equivalent absorption coefficient $\mathrm{F}(\mathrm{R})$ according to the Kubelka-Munk Function (Eq.(5)) [70].

$$
\mathrm{F}(\mathrm{R})=\frac{(1-R)^{2}}{2 R}
$$

For a direct transition semiconductor, the absorption coefficient near the absorption threshold can be expressed as Eq.(6) shows, where Eg is the optical band gap (eV), Bi the absorption constant, hv is photon energy and $\alpha$ is the absorption coefficient [70].

$$
\alpha=\frac{B i(h v-E g)^{1 / 2}}{h v}
$$

A transformed Kubelka-Munk function is constructed by plotting $(\mathrm{F}(\mathrm{R}) \mathrm{h} v)^{2}$ vs. photon energy (hv) (Figure.5 (b)). (F(R) hv) $)^{2}$ varied linearly with (hv) above the bandgap. Extrapolation of the straight line to zero absorbance locates an optical bandgap energy $\mathrm{E}_{\mathrm{g}}$ opt at $3.37 \mathrm{eV}$ for the $\mathrm{ZnO}$ flower-like. This value agrees well with the literature value of the electrodeposited $\mathrm{ZnO}[1,71$ 75] and is always attributed to the good crystallinity and to reduced number of defects in the $\mathrm{ZnO}$ flower-like.

\section{Conclusion}

In summary, we have investigated the structural and morphological properties of $\mathrm{ZnO}$ thin films fabricated by electrochemical deposition technique under a cathodic potential from a simple 
zinc nitrate aqueous solution at $70^{\circ} \mathrm{C}$ onto silicon n-type $\mathrm{Si}(100)$ substrates via a one-step rout only by changing electrodeposition duration and potential at a fixed concentration. The structural analysis has elucidated the polycrystalline nature of $\mathrm{ZnO}$ with a preferential orientation along (002) axis. The SEM studies showed that $\mathrm{ZnO}$ morphology changed from rods to flower-like as the electrodeposition potential deceased from $-1.4 \mathrm{~V}$ to $-1.2 \mathrm{~V}$. The resulting flower like $\mathrm{ZnO}$ morphology exhibited strong UV emission. This might be associated with a decrease in defect density in the flower-like $\mathrm{ZnO}$ morphology because of a decreased rate of nucleation.

The UV-visible spectrometry measurements also confirmed the good cristallinity of the flowerlike $\mathrm{ZnO}$ morphology with a bandgap of $3.37 \mathrm{eV}$.

The results obtained in this study demonstrate that the morphology of electrodeposited $\mathrm{ZnO}$ can be tailored by only varying the electrodeposition potential and duration without using any catalyst, additives, seed layer or post heat treatment.

\section{References}

[1] M. Dai, F. Xu, Y. Lu, Y. Liu, Y. Xie. Appl Surf Sci 2011 ; 257 : 3586.

[2] T. Pauporté, D. Lincot. Electrochim Acta 2000; 45: 3345.

[3] J. C. Johnson, H. Yan, Y. P. R. J. Saykally. J Phys Chem B 2003; 107: 8816.

[4] Y. R. Ryu, W. J. Kim, H. W. White. J Cryst Growth 2000; 219: 419.

[5] Z. L. Wang, J. Song. Sci 2006; 312:242.

[6] M. Law, L.E. Greene, J.C. Johnson, R. Saykally, P. Yang. Nature Materials 2005; 4: 4550.

[7] J. B. Baxter, A.M. Walker, K. Van Ommering, E. S. Aydil. Nanotechnology 2006; 17: S304.

[8] Z. Han, Li. Wei, Le. Tang, Ch. Cheng, H. Pan, J. Chen. Journal of Power Sources 2013; 239: 546.

[9] D. Karageorgopoulos, E. Stathatos, E. Vitoratos. Journal of Power Sources 2012; 219: 9. 
[10] J.H. Lee. Overview Sens Actuators B: Chem 2009; 1403:19-336.

[11] Y. H. Zhang, J. Liu, T. Liu, LP. You, XG. Li. J Cryst Growth 2005; 285: 541-8.

[12] ZL. Wang, XY. Kong, JM. ZuO. Phys Rev Lett 2003; 91:185502.

[13] XP. Gao, ZL. Wang. Appl Phys Lett 2004; 84:2883-5.

[14] JY. Lao, JY. Huang. DZ. Wang, ZF. Ren, Nano Lett 2003; 3:235-8.

[15] H. Gao, F. Yan, J. Li, Y. Zeng, J. Wang. J Phys D 2007;40:3654-9.

[16] Z. Fang, K. Tang, G. Shen, D. Chen, Mater Lett 2006 ;60:2530.

[17] J. Liu, X. Huanng, Y. Li, J. Duan, H. Ai. Mater Chem Phys 2006; 98:523.

[18] J. Wang, J. Cao, B. Fang, P. Lu, S. Deng, H. Wang. Mater Lett 2005;59:1405.

[19] Y. Kashiwaba, F. Katahira, K. Haga, T. Sekiguchi, H. Watanabe. J Cryst Growth 2000 ; $221: 431$

[20] V. Sallet, C. Thaindoume, J.F. Rommeluere, A. Kusson, A. Riviere, J.P.Riviere, O. Gorochov, R. Triboulet, V. Munoz-Sanjose. Mater Lett 2002; 53:126.

[21] Y. Natsume, H. Sakata. Thin Solid Films 2000; 372: 30.

[22] V. Musat, B. Teixeira, E. Fortunato, R.C.C. Monterio, Vilarinho. Surf Coat Technol 2004;180:659.

[23] W. Tang, D.C. Cameron. Thin Solid Films 1994; 238:83.

[24] V. Gupta, A. Mansingh. J Appl Phys 1996; 80:1063.

[25] X.W. Sun, R.F. Xaio, H.S. Kwok. J Appl Phys 1998;84 :5776.

[26] P. Nunes, E. Fortunato, R. Martins. Int J Inorg Mater 2001; 3:1125.

[27] H. Liu, G. Piret, B. Sieber, J. Laureyns, P. Roussel, W. Xu, R. Boukherroub, S. Szunerits. Electrochem Com 2009;11:945.

[28] N. Ait Ahmed, G. Fortas, H. Hammache, S. Sam, A. Keffous, A. Manseri, L. Guerbous, N. Gabouze. Appl Surf Sci 2010;256:7442.

[29] M. Eyraud, G.Jimenez-Cadena, C. Chassigneux, F. Vacandio, E. Comini, G. 
Sberveglieri, T. Djenizian. Int J Nanotechnol 2012;9:295.

[30] M.R. Khelladi, L. Mentar, M. Boubatra, A. Azizi. Mater Lett 2012;67:331.

[31] K.Q. Peng, Y. Wu, H. Fang, X.Y. Zhong, Y. Xu, J. Zhu. Angew. Chem Int Ed 2005; $44: 2737$.

[32] N. Ait Ahmed, M. Eyraud, H. Hammache, F. Vacandio, S. Sam, N. Gabouze P. Knauth, K. Pelzer, T. Djenizian. Electrochimica Acta 2013; 94: 238- 244.

[33] M. R. Khelladi, A. Beniaiche, L. Mentar, L. Makhloufi, A. Azizi. Journal of Materials Science: Materials in electronics, 2013;24:153-159.

[34] Ch-L. Cheng, J-S. Lin, Y. F. Chen. J. Alloys Compds 2008; 09:132.

[35] M. J. Zheng, L. D. Zhang, G. H. Li, W. Z. Shen. Chemical physics Letters 2002; 363:123128.

[36] Y. Leprince-Wang, G. Y. Wang, X. Z. Zhang, D. P. Yu. J Crysl Growth 2006;287:89-93.

[37] Y. Leprince-Wang, A. Y. Ouslim, G. Y. Wang. Microelectronics journal 2005; 36:625628.

[38] M. Lai, D.J. Riley. Chem Mater 2006; 18:2233.

[39] Z. Liu, Z. Jin, W. Li, X. Liu, G. Qiu, W. Wu. Materials Letters 2006; 60:810-814.

[40] F. Xu, L. Sun, M. Dai, Y. Lu. Journal of Physical Chemistry C 2010;114:15377.

[41] Q. Hou, L. Zhu, H. Chen, H. Liu W. Li. Electrochim. Acta 2012; 78: 55- 64

[42] C. Wu, X. Qiao, J. Chen, H. Wang. Mater Chem Phys 2007; 102:7-12.

[43] A. Pan, R. Yu, S. Xie, Z. Zhang, C. Jin, B. Zou. J Cryst Growth 2005; 282:165-72.

[44] JW. Zhao, LR. Qin, ZD.Xiao, LD. Zhang. Mater Chem Phys 2007; 105:194-7.

[45] H. Zhao, X. Sua, F. Xiao, J. Wang, J. Jian. Materials Science and Engineering B 2011; 176: $611-615$.

[46] P. Rai, J.N. Jo, I.H. Lee, Y.T. Yu. Materials Chemistry and Physics 2010; 124 :406-412.

[47] Y-Ch. Liang. Ceramics International 2012; 38:1697-1702. 
[48] F. Xu, Y. Lu, Y. Xie, Y. Liu. Materials and Design 2009; 30:1704-1711]

[49] F. Xu, Y. Lu, Y. Xie, Y. Liu. Vacuum 2009; 83:360-365.

[50] J-li. Yang, Gu. T. Fei, Hu. Li, H-mi. Ouyang. Chin. J. Chem. Phys, 2012; 25:339.

[51] A.P. Alivisatos. Sci 1996; 271:933.

[52] T. Pauporte, J. Rathousky. Microporous and Mesoporous Materials, 2009; 117:380-385.

[53] Y. Zhang, J. Weng, Y. Zhang, L. Xu, J. Xu Xi. Huang, K. Chen. Physica E 2005; 27:183187.

[54] Ch. Gu, J. Li, J. Lian, Gu. Zheng. App Surf Sc 2007; 253:7011-7015.

[55] M. Izaki, T. Omi. Appl Phys Lett 1996 ;68:2439.

[56] E.A. Dalchiele, P. Giorgi, R.E. Marotti, F. Martin, J.R. Ramos-Barrado, R. Ayouci, D. Leinen. Sol Ener Mater Sol C 2001;70:245.

[57] R.E. Marotti, D.N. Guerra, C. Bello, G. Machado, E.A. Dalchiele. Sol Ener Mater Sol C $2004 ; 82: 85$.

[58] T. Pauporte, D. Lincot. J Electrochem Soc 2001; 148:310.

[59] T. Pauporte. Crystal Growth Des 2007;7:2310.

[60] C.S. Barret, T.B. Massalski. Structure of Metals, Pergamon Press, Oxford, 1980.

[61 ] Joint Committee on Powder Diffraction Standards, Powder Diffraction File PDF 01077-0488 card for SnO2; Powder Diffraction File, Card 36-1451, Joint Committee on Powder Diffraction. Standards, ICDD, Newtown Square (PA) 2001.

[62] A. Umar, YB. Hahn. Nanotechnology 2006;17:2174.

[63] A. Umar, YB. Hahn. Appl Phys Lett 2006; 88:173120.

[64] B. Liu, Z. Fu, Y. Jia. Appl Phys Lett 2001;79:943.

[65] K. Vanheusden, W.L. Warren, C.H. Seager, D.R. Tallant, J.A. Voigt, B.E. Gnade. J. Appl Phys 1996; 79:7983-7990. 
[66] M. Godlewski, E. M. Goldys, M.R. Phillips, R. Langer, A. Barski. Appl Phys Lett $1998 ; 73: 3686-8$.

[67] Z. Fang, Y. Wang, D. Xu, Y. Tan, X. Liu. Opt Mater 2004;26:239.

[68] X. Mathew, P.J. Sebastian, A. Sanchez, J. Campos. Sol Energy Mater Sol Cells 1999;59:99.

[69] G. Riveros, H. Gomez, R. Henriquez, R. Schrebler, R.E. Marotti, E.A. Dalchiele.

Boletiın de la Sociedad Chilena de Quimica, 2002 ; 47:411.

[70] C.-T. Wang, S. -H. Ro, Ch.-S. Jao, M.-K. Tsi, S.-Y. Yang, J Non-Crys Sol 2010;356: 873878.

[71] Y. Chen, D. M. Bagnall, H.-J. Koh, K.-T. Park, K. Park, K. Hiraga, Z. Zhu, T. Yao. J. Appl. Phys, 1998; 84:3912.

[72] Y. Jin, J. Wang, B. Sun, J. Sun, J. C. Blakesley, N. C. Greenham. Nanolett 2008; 8:1649.

[73] Z.G.Chen, Y.W.Tang, L.S. Zhang, L.J. Luo. Electrochim Acta 2006; 51:5870.

[74] F. Xu, Y. Lu, Y. Xie, Y. Liu. Vacuum 2009;83:360-365.

[75] B. Theys, V. Sallet, F. Jomard. J Appl Phys 2002; 91:3922. 


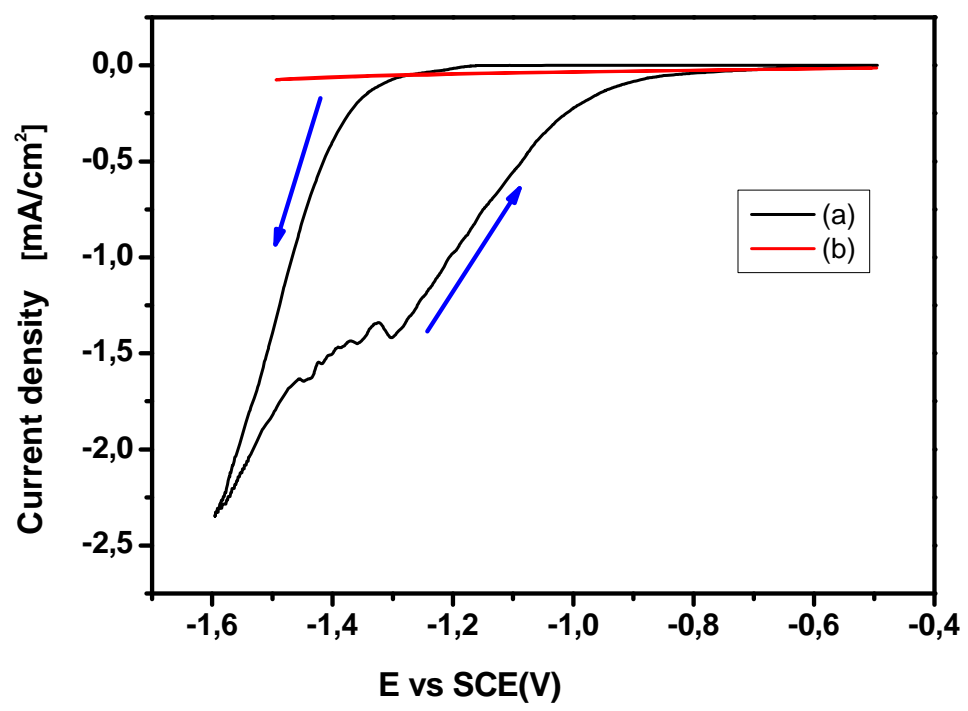

Fig.1. Cyclic voltammograms measured at a silicon electrode in: (a) $78.10^{-4} \mathrm{M}$ $\mathrm{Zn}\left(\mathrm{NO}_{3}\right)_{2}$ and (b) $0.1 \mathrm{M} \mathrm{KNO}_{3}, \mathrm{~T}=70^{\circ} \mathrm{C}$, scan rate $=5 \mathrm{mV} / \mathrm{s}$.

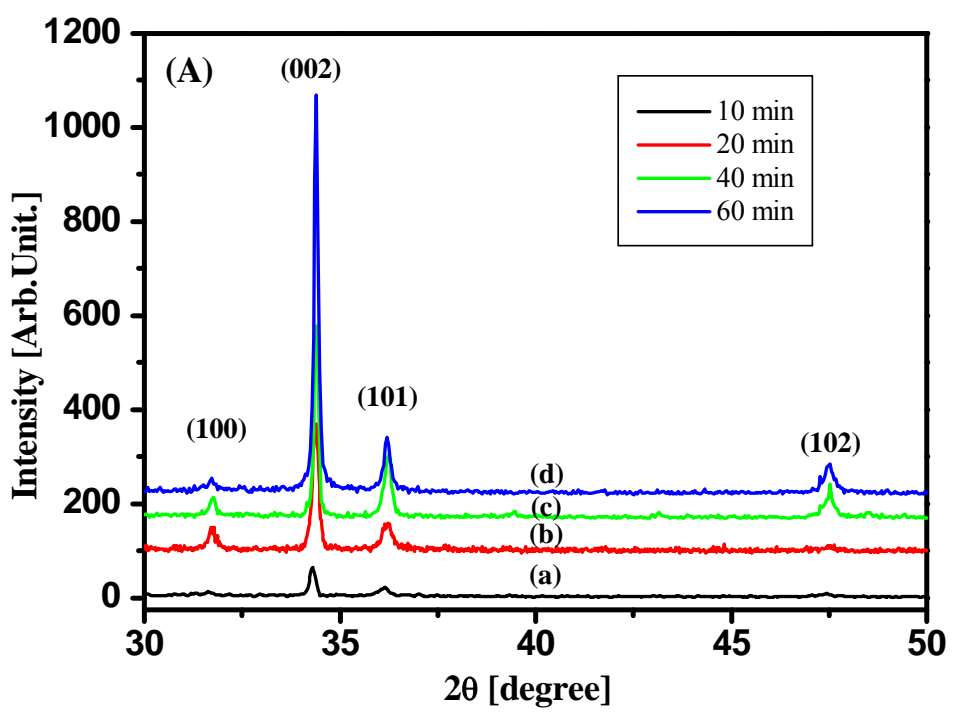




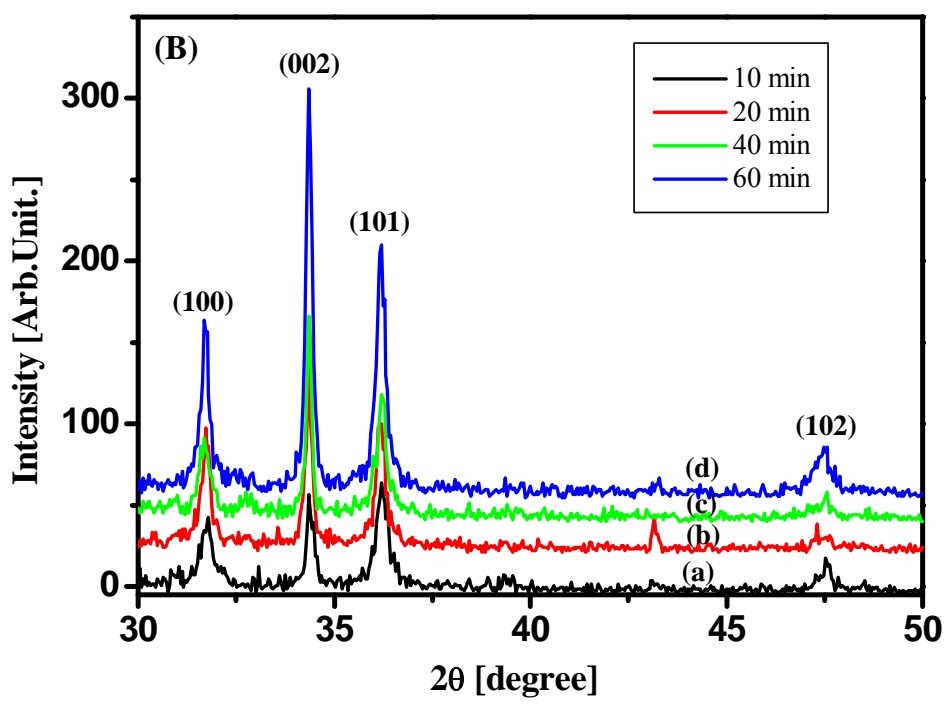

Fig.2. X-ray diffraction patterns of $\mathrm{ZnO}$ deposited on Si substrate at different durations and applied potentials: $(\mathrm{A}) \mathrm{de}-1.2 \mathrm{~V},(\mathrm{~B}) \mathrm{de}-1.4 \mathrm{~V},\left[\mathrm{Zn}\left(\mathrm{NO}_{3}\right)_{2}\right]=0.0078 \mathrm{M}$ and $\left[\mathrm{KNO}_{3}\right]=0.1 \mathrm{M}$.

Table.1. Values of texture coefficient of $\mathrm{ZnO}$ electrodeposited on $\mathrm{Si}$ at different durations and applied potential: $-1.4 \mathrm{~V}$ et $-1.2 \mathrm{~V},\left[\mathrm{Zn}\left(\mathrm{NO}_{3}\right)_{2}\right]=0.0078 \mathrm{M}$ et $\left[\mathrm{KNO}_{3}\right]=0.1 \mathrm{M}$.

\begin{tabular}{|l|l|l|l|l|}
\hline \multirow{2}{*}{$\mathrm{ZnO} / \mathrm{Si}$} & \multicolumn{4}{|c|}{ TC $_{\mathbf{I}(002)}$} \\
\cline { 2 - 5 } & $10 \mathrm{~min}$ & $20 \mathrm{~min}$ & $40 \mathrm{~min}$ & $60 \mathrm{~min}$ \\
\hline$-1.4 \mathrm{~V}$ & 1.49 & 2.10 & 2.15 & 2.35 \\
\hline$-1.2 \mathrm{~V}$ & 2.4 & 2.86 & 2.87 & 2.99 \\
\hline
\end{tabular}

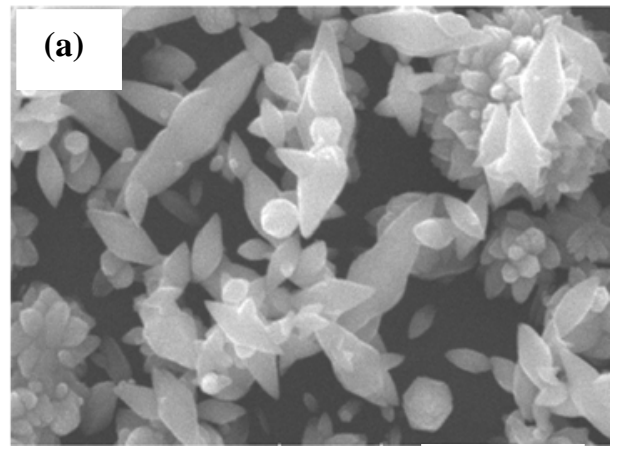

$2 \mu \mathrm{m}$

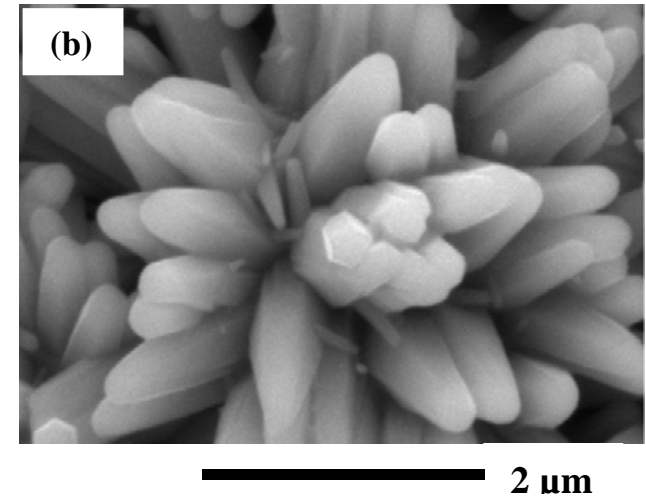




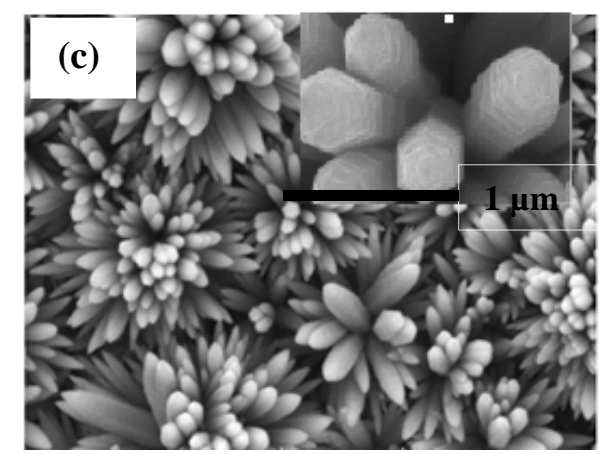

$10 \mu \mathrm{m}$

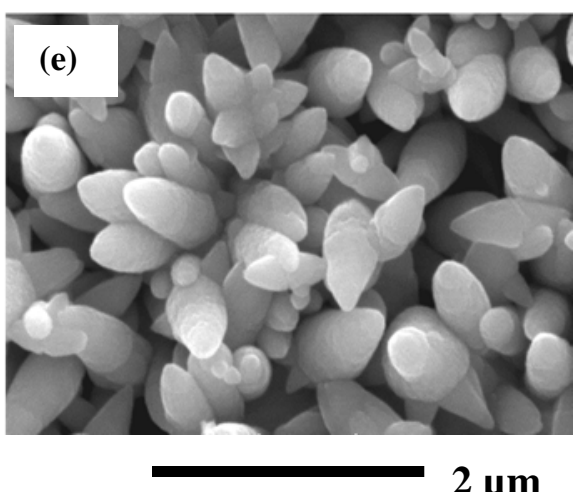

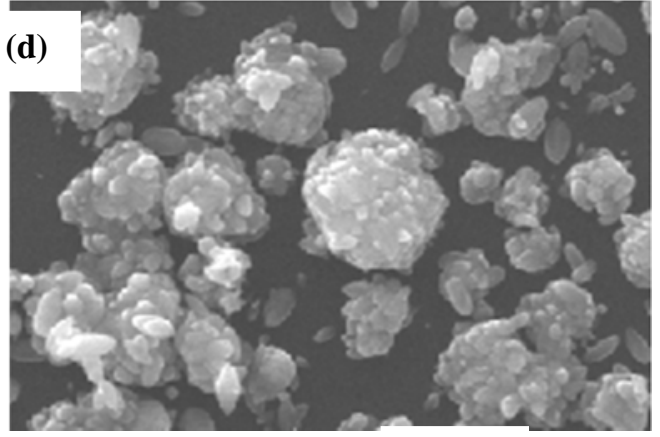

$2 \mu \mathrm{m}$

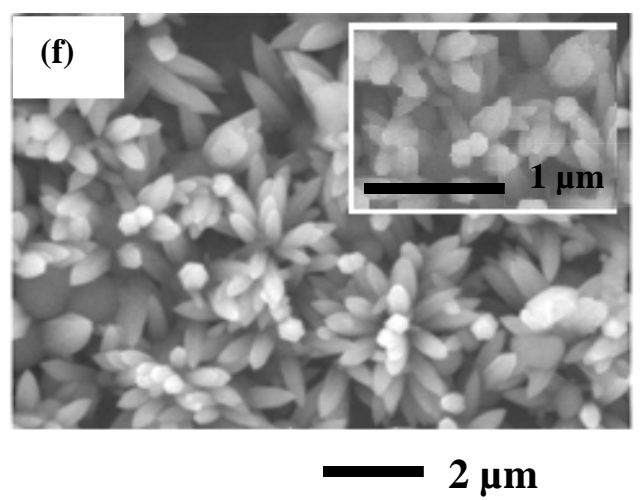

Fig.3

Fig.3. SEM images of ZnO nanorods deposited on Si substrate at different potential deposition and different durations: $(a, b, c)$ at $-1.2 \mathrm{~V}$ and $(d, e, f)$ at $-1.4 \mathrm{~V}$ for 20,40 and 60 min respectively, $\left[\mathrm{Zn}\left(\mathrm{NO}_{3}\right)_{2}\right]=$ $0.0078 \mathrm{M}$ and $\left[\mathrm{KNO}_{3}\right]=0.1 \mathrm{M}$.

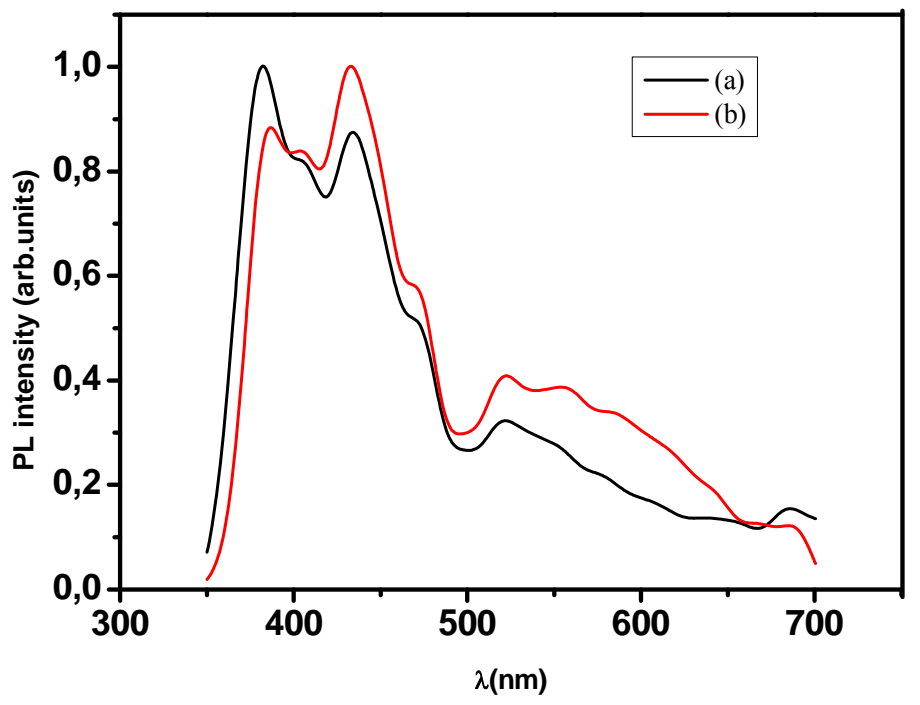


Fig.4. PL spectra of $\mathrm{ZnO}$ electrodeposited on Si substrate at different applied potentials: (a)-1.2V and (b) $-1.4 \mathrm{~V}$ for 60min, $\left[\mathrm{Zn}\left(\mathrm{NO}_{3}\right)_{2}\right]=78.10^{-4} \mathrm{M}$
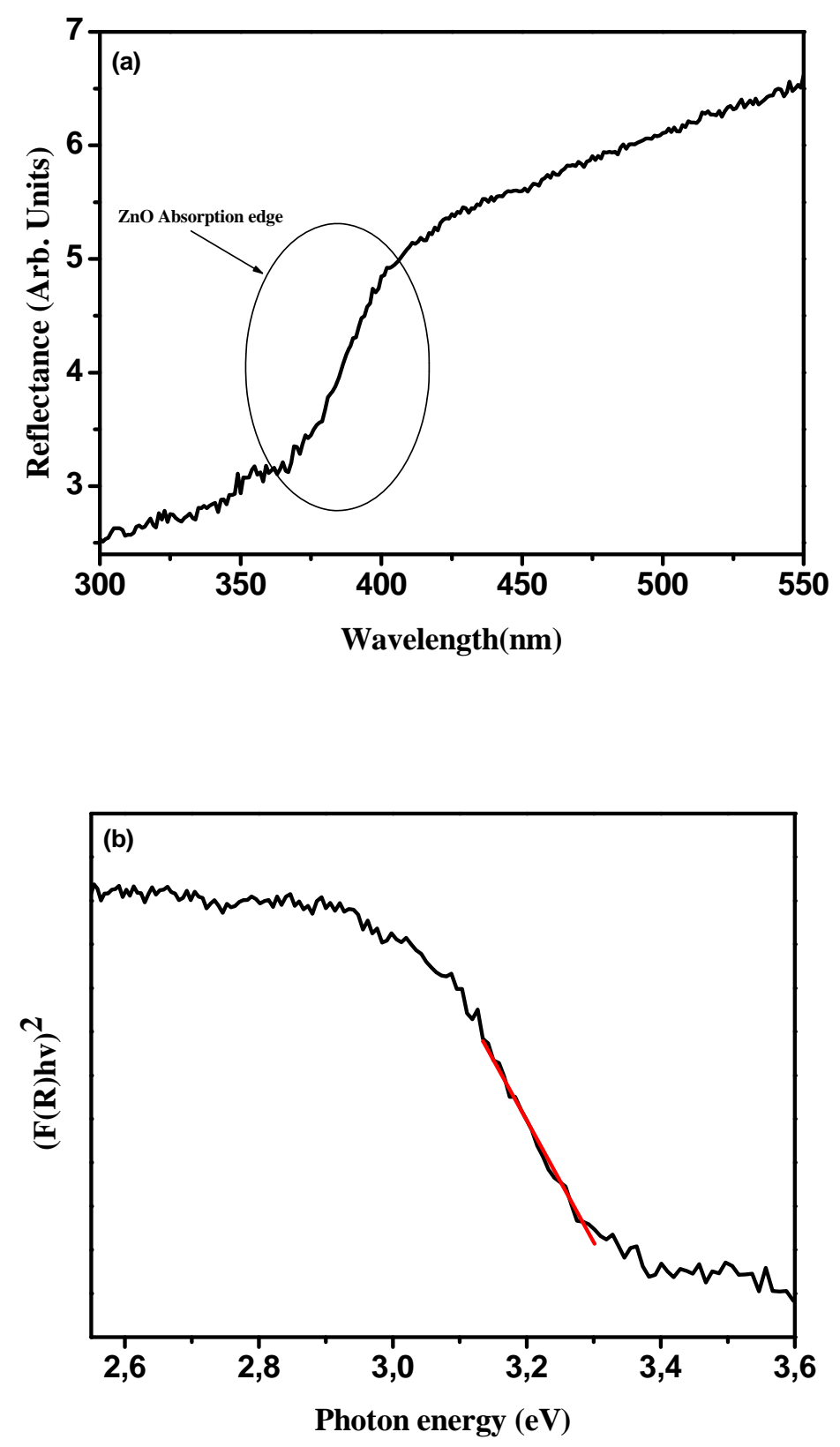

Fig.5

Fig.5. (a) Diffuse reflectance spectra of $\mathrm{ZnO}$ deposited at $-1.2 \mathrm{~V}$ for 60min, (b) $(F(R) h v)^{2}$ vs. photon energy (hv) 
